\title{
Does Ownership Concentration Affect Profitability and Dividend Policy? Evidence from Listed Banks in Jordan
}

\author{
AHMAD DAHIYAT \\ Department of Accounting/ Amman College, Al Balqa Applied University \\ JORDAN \\ ESRA AL-NSOUR \\ Department of Accounting/ Amman College, Al Balqa Applied University \\ JORDAN
}

\begin{abstract}
This paper examines how the ownership concentration affects banks' profitability and dividend policy in Jordan. All banks listed on the Amman Exchange were selected (16 banks) over the period 2010 to 2019. Ownership concentration was defined as the percentage of ownership that equals or exceeds $5 \%$, while profitability was defined by return on equity; dividend policy was defined by the pay-out ratio.

Simple regression was utilized to examine the effect; the result revealed that ownership concentration has a positive significant impact on profitability, which means that banks with higher ownership concentration have better profitability, this result justified by the view of the power that controlling shareholders can greatly use to require management to make decisions that improve the performance.

The finding showed a negative significant impact on dividend policy, which indicates that the existence of large shareholders can reduce agency conflicts; and maximize the wealth of the company.

It is recommended that related parties especially investors should take the concentration of ownership as an important factor to take their investment decisions, whether related to purchasing banks' shares for various purposes, or expectations of potential dividends.
\end{abstract}

Keywords: Ownership structure, Return on equity, Dividend pay-out, Banks, Ownership concentration

Received: January 18, 2021. Revised: June 24, 2021. Accepted: June 28, 2021. Published: July 6, 2021.

\section{Introduction}

The banking sector in Jordan appears to play a critical role in the economy; this is evident when looking at the statistics related to the assets of licensed banks, which was reached USD 71.82 billion at the end of 2018 [7]. Profitability is an important aspect and goal that organizations in general and banks have tried to achieve to support their financial position and build strong buffers to absorb additional losses. Besides, profitability is considered a vital tool to judge management's effectiveness and efficiency in the use of resources.

On the other hand, dividend policy is a controversial issue, due to disagreements on many aspects, for example: should a portion of the profits be distributed to the shareholders, or should dividends reserve to 
finance expansion and growth? Therefore, dividend policy is considered one of the key decisions taken by managers.

The Concentration of ownership describes the large number of shares owned by a controlling owner who holds at least $5 \%$ of a company's shares and hence may practice control on managerial decisions. Two conflicts between shareholders and managers have been identified and considered, they found to be related to the main agency problem; the first one arises because managers do not receive the whole profit generated from their efforts in managing the resources of the company, although the fact that they bear the whole costs resulting from their activities, while the second one is the danger of seizure by the overwhelming investor to the detriment of minority investors [20].

This paper examines whether ownership structure, measured by ownership concentration, affects profitability and dividend policy, using all the listed banks in Jordan throughout 2010 to 2019, and explores the possible association between ownership structure and banks' profitability and dividend policy over the period of 2010 2019.

\section{Literature Review}

\subsection{Relationship between ownership concentration and performance}

Many empirical studies have been performed to analyze the relationship between ownership concentration and financial performance, the studies reached contradictory findings. The study of Pervan, et.al (2012) [29], which was conducted in Croatia in the period 2003-2010, concluded that there is a negative association between the concentration of ownership and performance. While Nikolić, Babić \& Erić (2013) [26] found that there is no significant effect of ownership concentration on the profitability of 146 companies in Serbia. Zhang \& Kyaw (2017) [35] applied their study on Chinese companies, they found a positive association between firm performance and institutional ownership, while the Ownership concentration and state ownership did not affect firm performance. on the other hand, a study of (Abazi-Alili, 2013) [1] which was applied to private companies in Macedonia, confirmed a positive relationship between ownership concentration and profitability, Ozel \& Uadiale (2017) [28] found also a positive association between ownership concentration and return on assets, the same results were presented by Gugong et al. (2014) [17] and Huang (2020) [19] who found a positive relationship between ownership concentration and Chinese bank profitability, and the relationship was negatively moderated by bank size.

the study of (Meca, - Ballesta 2011) [15] found that the main ownership structure mechanism that affects the value of the company is ownership concentration, the results indicate that the ownership concentration is positively associated with the value of the company.

The Studies of (Shan a\& Gong, (2017) [31] Chatterjee \& Bhattacharjee (2020) [11] also concluded a positive relationship between ownership concentration the performance.

\subsection{Relationship between ownership concentration and dividends}

Concerning the relationship between ownership structure and dividends payout, it is essential to mention that management incorporation faces three types of decisions. One of them is the type of assets the firm needs to acquire, the other is about how to finance these assets, and the third is concerned with the portion of the earned profits that it should distribute (Malkawi et al., 2010) [23]. Typically, managers concentrate on the impact of these distributions on the price of the stock, and how the stable dividends affect the 
satisfaction of investors, who prefer bonds that pay regular and stable interest payments. Hence, managers determine the portion of earned income that they should retain to reinvest in the business to maximize shareholders' wealth.

From another perspective, dividends are considered the source of information that helps investors make assessments about the extent of success the firm has in its operations, rather than reported earnings. However, there are three main approaches to dividends: The first approach dictates that a large number of dividends will enhance the value of the corporation (bird in the hand). In contrast, another approach dictates that high dividends will diminish the corporation's value (the tax preference), and the third approach considers that dividends should be irrelevant to the corporation's value (dividend irrelevance; Milbourn et al., 2006 [25]).

Fama and Jensen (1983) [14] stated that dispersion of ownership, which aims to separate the decision-making function and the risk-bearing function in large companies, will make efficiency benefits exceeds the agency costs.

Previous studies have considered two main aspects of how ownership concentration affects dividends payout: positive relationship and negative relationship. In Jordan, Al-Shubiri et al. (2011) [6], found a significant inverse relationship between ownership concentration and dividend per share. The study also found a positive relationship between ownership of the five largest shareholders and the size of the dividend payment.

A study by (Al Malkawi et al., 2013) [24] that focused on companies listed in the financial sector in Saudi Arabia (2005 to 2011) concluded that that ownership structure and investment opportunities did not affect dividend policy.

A study by Arshad et al. (2013) [5] investigated companies listed in the Karachi stock exchange (2007 - 2011) (information, communication, and transportation sectors) revealed a potential correlation between the type of capital structure and dividend payout and decisions.

Kulathunga and Azeez (2016) [21] found that there is a positive association between concentrated corporate capital and dividend policy. a study by Reyna (2017) [27] that looked at Mexican banks stated that concentration of ownership in families negatively affects dividends. Another study by Farrukh et.al (2017) [33] dictates that dividend policy has a significant correlation with firms' performance measured by return on equity.

Gonzalez et.al (2017) [16] found that there is a significant and inverse correlation between a corporate capital that consists of controlling shareholders and dividends payout. Another study by Arora, (2019) [4] found that there is a positive and significant relationship between corporate capital structure and dividends payout, in other words, if the capital of a firm consists of a controlling group and owners who possess a large number of the company's stocks, then this type of capital has an inverse effect on the dividend policy.

considering the studies that have been reviewed whether those that deal with the impact of ownership structure on performance or those that talked about the impact of ownership structure on dividends, and in light of the different results, this study is unique in that it will determine the impact of concentration of ownership on profits as well as on the dividends policy of the listed banks in Jordan, and during a relatively long period (2010-2019).

\subsection{Study hypotheses}

As such, the following hypotheses were formulated to achieve that purpose.

H01: There is no significant effect of ownership concentration on the profitability of all listed banks in Amman Stock Exchange 
H02: There is no significant effect of ownership concentration on dividends policy of all listed banks on the Amman Stock Exchange.

\section{Data and Methods}

\subsection{Data Collection and Sample}

This study is a descriptive, analytical study. Data related to this study are extracted from the financial statements from2010 to 2019 of all listed banks on Amman Stock Exchange.
The research sample covers all Banks listed on Amman Stock Exchange which are 16 banks (Jordan depository center, 2020 [30]).

\section{2 selection of Variables \\ 3.2.1. Dependent variable}

The first variable is the profitability that was measured by Return on equity "ROE" [34]. The second variable is the dividend policy that was measured by the Payout [32], [18].

\subsubsection{Independent variable}

Ownership concentration means the percentage of those who own $5 \%$ or more to total ownership ([10], [8], [9])

The following table, clarifies the measures of study's variables:

Table (1) the definitions and measures of variables

\begin{tabular}{|l|l|l|}
\hline $\begin{array}{l}\text { Dependent } \\
\text { Variable }\end{array}$ & Variable & Measurement Method \\
\hline $\begin{array}{l}\text { Independen } \\
\text { t Variable }\end{array}$ & Profitability & Dividends per share/Earning per share \\
\hline $\begin{array}{l}\text { Independen } \\
\text { t Variable }\end{array}$ & $\begin{array}{l}\text { Ownership } \\
\text { concentration }\end{array}$ & Ownership of those with 5\% or more/total ownership \\
\hline
\end{tabular}

\subsection{Statistical Methods}

To examine the effect of ownership concentration on profitability and dividends policy, statistical methods such as regression and correlation were used. Statistical Package for Social Science (SPSS) was used in analyzing data for (16) listed banks for the period (2010-2019).

\section{Results}

The paper first examined the relationship between ownership concentration and bank's profitability, and tested the first hypotheses, then it examined the relationship between 
ownership concentration and dividends policy and tested the second hypotheses.

\subsection{The statistical results of the first Hypotheses}

H01: There is no significant effect of ownership concentration on a bank's profitability.

Tables $(2,3)$ below shows the result of statistical analysis:

Table (2): Empirical work

\begin{tabular}{|c|c|c|c|c|c|}
\hline Hypothesis & \multicolumn{2}{|l|}{$\mathrm{R}$} & \multicolumn{3}{|l|}{ R Square } \\
\hline 1 & $0.892(a)$ & & 0.795 & & \\
\hline Model & $\begin{array}{l}\text { Sum of } \\
\text { Squares }\end{array}$ & Df & Mean Square & $\mathrm{F}$ & Sig. \\
\hline $\begin{array}{l}\text { Regression } \\
\text { Residual } \\
\text { Total }\end{array}$ & $\begin{array}{l}0.167 \\
0.43 \\
0.210\end{array}$ & $\begin{array}{l}1 \\
158 \\
159\end{array}$ & $\begin{array}{l}16.7 \\
0.003\end{array}$ & 50.366 & 0.00 (a) \\
\hline
\end{tabular}

a Predictors: ownership concentration

$\mathrm{b}$ dividend policy

Table (3): Analysis of Regression Coefficient

\begin{tabular}{|l|l|l|l|l|l|l|}
\hline Model & & \multicolumn{2}{|l|}{$\begin{array}{l}\text { Unstandardized } \\
\text { Coefficients }\end{array}$} & $\begin{array}{l}\text { Standardized } \\
\text { Coefficients }\end{array}$ & $\mathrm{T}$ & Sig. \\
\hline & & B Slope & Std. Error & Beta & & \\
\hline & & -4.574 & 0.672 & & -6.803 & 0.00 \\
& (Constant) & 0.554 & 0.078 & 0.892 & 7.097 & 0.00 \\
\hline
\end{tabular}

The value of (f) is significant at $\alpha=5 \%$, therefore the null hypothesis is rejected, this refers that ownership concentration has a significant effect on profitability, table 2 and table 3 show that the predictor variable (ownership concentration) helps in the prediction of profitability with a B-coefficient of (0.554) at the same time the value of ( $\mathrm{T}$ and sig-) also indicates that ownership concentration generates a significant positive impact on profitability, the equation for prediction of profitability would be as the following:

Profitability $=-4.574+0.554 \times$ Ownership concentration

This equation shows that an increase in ownership concentration is accompanied by an increase in profitability; however, it is not easy to explain the effect of the ownership concentration variable through factor (B) of (0.554). The explanation of this effect is easier when the parameter is calculated after taking into consideration Z-Score for both dependent and independent variables. The case is equal to the value of the correlation coefficient between the two variables, which is Beta. It is used to predict the standard value of the dependent variable by the independent values of the independent variable. The value of Beta is 0.892 . This means that the increase of the independent variable (ownership concentration) by one unit will increase profitability by 0.892 .

The outcome of this paper is agreed with 
numerous articles, which dictates that there is a positive relationship between ownership

concentration and profitability ([28], [17], [1]).

\subsection{The statistical results of second Hypotheses}

H02: There is no significant effect of bank's ownership concentration on Dividend's policy.

Tables $(4,5)$ below shows the result of statistical analysis:

Table (4): Model Summary

\begin{tabular}{|c|c|c|c|c|c|}
\hline Hypothesis & \multicolumn{2}{|l|}{$\mathrm{R}$} & \multicolumn{3}{|l|}{ R Square } \\
\hline 2 & $0.410(\mathrm{a})$ & & 0.168 & & \\
\hline Model & Sum of Squares & Df & Mean Square & $\mathrm{F}$ & Sig. \\
\hline $\begin{array}{l}\text { Regression } \\
\text { Residual } \\
\text { Total }\end{array}$ & $\begin{array}{l}18235.468 \\
90474.968 \\
108710.436\end{array}$ & $\begin{array}{l}1 \\
158 \\
159\end{array}$ & $\begin{array}{l}18235.468 \\
572.626\end{array}$ & 31.845 & $0.00(a)$ \\
\hline
\end{tabular}

a Predictors: ownership concentration

$\mathrm{b}$ dividend policy

Table (5): Analysis of Regression Coefficient(a)

\begin{tabular}{|l|l|l|l|l|l|l|}
\hline \multirow{2}{*}{ Model } & & \multicolumn{2}{|l|}{$\begin{array}{l}\text { Unstandardized } \\
\text { Coefficients }\end{array}$} & $\begin{array}{l}\text { Standardized } \\
\text { Coefficients }\end{array}$ & $\mathrm{T}$ & Sig. \\
\hline \multirow{2}{*}{1} & & $\mathrm{~B}$ & Std. Error & Beta & & \\
\hline & (Constant) & 84.182 & 6.312 & & 13.337 & 0.00 \\
& IND & -0.567 & 0.100 & -0.410 & -5.643 & 0.00
\end{tabular}

a dividend policy

The value of (f) is significant at $\alpha=5 \%$, therefore the null hypothesis is rejected, this leads to a conclusion that ownership concentration has a significant impact on the Dividends policy, statistical analyses show that the predictor variable (ownership concentration) assigns to forecasting of Dividends policy with a B-coefficient of (0.567 ) in addition to values of T statistics and sig- which indicates that ownership concentration generates a significant negative impact on dividends policy, The equation for prediction of dividends policy would be as follow:

Dividends policy $=84.182-0.567 \times$ Ownership concentration

This equation shows that a decrease in ownership concentration is accompanied by an increase in dividends payout; however, it is not easy to explain the effect of the ownership concentration variable through 
factor (B) of (0.567-). The explanation of this effect is easier when the parameter is calculated after the calculation of Z-Score for both dependent and independent variables. the value of the correlation coefficient between the two variables is equal, which is Beta. It is used to predict the standard value of the dependent variable by the independent values. The value of Beta is 0.410. This means that the decrease of the independent variable (ownership concentration) by one unit will increase the dividend payout by

\section{Discussion}

\subsection{The first hypothesis:}

The researchers finding of the first hypothesis that an increase in ownership concentration is accompanied by an increase in profitability; researchers justified the first hypothesis result, as the ownership concentration increases, it is expected that the owners of the large shares will exercise some form of control on the management, which may enhance the performance of the bank, this result is consistent with several studies mentioned in the above section (Results).

\section{Conclusion Recommendations}

This paper has investigated the impact of the corporate capital structure measured by ownership concentration on profitability and dividends policy of recorded Jordanian banks over the period (2010-2019). It demonstrated a significant positive impact of ownership concentration on profitability, which means that banks with a high ownership concentration have better profitability, and this may be because of the active monitoring of shareholders with a high percentage of ownership on the management of the bank, which may lead management to make decisions that are reflected positively on owner' equity, thus improving profitability. The study also found an inverse impact of ownership concentration on the Dividends policy, which implies that expansion of ownership concentration prompts to decline
0.410 .

The study found an inverse relationship between ownership concentration and Dividends policy, and this agrees with study [21] and study [27], and can be justified by agency theory, which suggests that the existence of ownership concentration may reduce agency conflicts, and maximize the wealth of the company.

\subsection{The second hypothesis}

The researchers concluded that an increase in ownership concentration is accompanied by a decrease in dividends payout; the result of the second hypothesis may be justified by the desire of the major shareholders who control the decisions in the bank, including the decisions of retaining profits or distributing them, to maximize the value of the company, this result is consistent with several studies mentioned in the above section (Results).

dividends payout and vice versa, which means that the existence of big ownerships may reduce agency conflicts and maximize the wealth of the bank.

According to previous conclusions, it is recommended that related parties such as investors, financial analysts should take the concentration of ownership as an important factor to take their different decisions, whether related to purchasing banks' shares for various purposes, or expectations of potential dividends. Furthermore, it is recommended to encourage concentrated bank ownership to take benefits from control benefits and improve banks' profitability, and to conduct future research to examine the impact of institutional ownership and foreign ownership and governmental ownership on both, bank profitability and dividends payout in developing countries. 


\section{References:}

[1] Abazi-Alili, Hyrije. "THE EVOLUTION OF OWNERSHIP, INNOVATION AND FIRM PERFORMANCE: EMPIRICAL EVIDENCE FROM MACEDONIA." DIEM: Dubrovnik International Economic Meeting. Vol. 1. No. 1. Sveučilište u Dubrovniku, 2013.

[2] Amman stock exchange, Cumulative data report, available on: https://www.ase.com.jo/en/Investors/Comp anies-Guide/Cumulative-Data, (2021)

[3] Amman stock exchange, financial statements of manufacturing companies available on:

https://www.ase.com.jo/ar/disclosures (2021)

[4] Arora Ravinder Kumar, 1Aman Srivastava, Ownership Concentration andDividend Payout in Emerging Markets: Evidence from India, Global Business Review (2019), PP. $1-13$

[5] Arshad, Z., Akram, Y., Amjad, M., \& Usman, M.. Ownership structure and dividend policy. Interdisciplinary Journal of Contemporary Research in Business, 5(3), (2013) PP.378-401.

[6] Al-Shubiri, F. N.. Determinants of changes dividend behavior policy: the Far East Journal of Psychology and Business, 4(1), (2011)PP.1-15.

[7] Association of Banks, report of 2019, Amman-Jordan, available on: https://www.abj.org.jo retrieved date: 26/6/2019

[8] Baba, N., \& Packer, F.. From turmoil to crisis: dislocations in the FX swap market before and after the failure of Lehman Brothers. Journal of International Money and Finance, 28(8), (2009), PP.1350-1374.

[9] Castrillo Lara, L. Á., \& San Martín Reyna, J. M.. La propiedad familiar como mecanismo de gobierno disciplinador de la dirección en las empresas mexicanas: una evidencia empírica. Contaduría y administración, (222), (2007) PP.59-82.

[10] Chai, D. H. Foreign corporate ownership and dividends. Centre for Business Research, University of Cambridge(2010).

[11] Chatterjee, M., \& Bhattacharjee, T..
Ownership concentration, innovation and firm performance: empirical study in Indian technology SME context. South Asian Journal of Business Studies. (2020).

[12] Easterbrook, F. Two agency-cost explanations of dividends. American Economic Review, 74, (1984) PP.650- 659.

[13] Fama :Micheal,Agency Problems and the Theory of Firm February, Journal of Political Economy 88(2): 1980 PP.288-307

[14] Fama; Michael C. Jensen Separation of Ownership and Control Eugene F Journal of Law and Economics, Vol. 26, No. 2, Corporations and Private Property the Hoover Institution. (Jun., 1983), pp. 301325.

[15] García- Meca, E., \& Sánchez- Ballesta, J. P. Firm value and ownership structure in the Spanish capital market. Corporate Governance: The international journal of business in society. (2011).

[16] Gonzalez, M., Molina, C. A., Pablo, E., \& Rosso, J. W., the effect of ownership concentration and composition on dividends: Evidence from Latin America Emerging Markets Review Volume 30, March, (2017) PP. 1-18

[17] Gugong, B. K., Arugu, L. O., \& Dandago, K. I.. The impact of ownership structure on the financial performance of listed insurance firms in Nigeria. International Journal of Academic Research in Accounting, Finance and Management Sciences, 4(1), (2014) pp.409-416.

[18] Harada, K., and Nguyen, P. "Dividend change context and signaling efficiency in Japan",Pacific-Basin Finance Journal, Vol. 13, (2005) pp. 504-522.

[19] Huang, Q. (2020). Ownership concentration and bank profitability in China. Economics Letters, pp.196, 109525.

[20] Jensen, M.C. and W.H. Meckling, , "Theory of the Firm: Managerial Behavior, Agency Costs and Ownership Structure," Journal of Financial Economics 3, 1976 pp.305-360.

[21] Kulathunga, K. M. K. N. S., \&Azeez, A. A. The impact of ownership structure on dividend policy: In Annual International Conference on Qualitative \& Quantitative 
Economics Research . (2016, January) (pp. 80-88).

[22] Leković, B., \& Marić, S.. The nature of corporate governance and performance in the conditions of ownership concentration. Industrija, 44(1), (2016) pp.45-61.

[23] Malkawi Al, and M.Rafferty,R.Pillai(2010),"Dividend policy:A review of theories" International Bulletin of business administration 9.

[24] Malkawi, Husam-Aldin N., Abdullah E. Twairesh, and Khadija Harery. "Determinants of the likelihood to pay dividends: Evidence from Saudi Arabia." Journal of American Science 9.12: (2013) pp.518-528

[25]

T,„M.Faulkender,A.Thakor"capital structure and dividend policy: Two sides of the same coin?Research gate, March 2006.

[26] Nikolić, J., Babić, V., \& Erić, J.. Ownership structure and corporate financial performance in Serbia: empirical evidence. Actual Problems of Economics, 9(147), (2013) pp.446-455.

[27] Reyna, J. M. S. M.. Ownership structure and its effect on dividend policy in the Mexican context. Contaduría Administración, 62(4), (2017), pp. 11991213.

[28] Ozili, P. K., \& Uadiale, O.. Ownership concentration and bank profitability. Future Business Journal, 3(2), (2017) pp.159-171.

[29] Pervan, M., Pervan, I., \& Todoric, M. Firm ownership and performance: Evidence for Croatian listed firms. World Academy of Science, Engineering and Technology, 61(2012), 964-970.

[30] Securities depository center, Public shareholding companies report-Banking sector, available on: https://www.sdc.com.jo/english/index.php. [31] Shan, H., \& Gong, G.. The impact of ownership structure on firm performance: static and dynamic panel data evidence from china's listed companies. National Convention on Sports Science of China, (2017) (p. 01017). EDP Sciences.
[31] Soondur, S. A. K., Maunick, D., \& Sewak, S.. Determinants of the dividend policy of companies listed on the stock exchange of Mauritius. In Proceedings of the Fifth AsiaPacific Conference on Global Business, (2016), Economics, Finance and Social Sciences.

[32] Farrukh, K., Irshad, S., Khakwani, M. S., Ishaque, S., \& Ansari, N. Y.. Impact of dividend policy on shareholders wealth and firm performance in Pakistan. Cogent Business \& Management, 4(1), (2017) p 1408208.

[33] Zeitun, Rami and Gary Gang Tian,"Does ownership affect a firm's performance and default risk in Jordan?", Corporate Governance: The international journal of business in society, Vol. 7 Iss 1 (2007)pp. 66 -82 .

[34] Zhang, H., \& Kyaw, K. Ownership structure and firm performance: An empirical analysis of Chinese companies. Applied Economics and Finance, 4(2), (2017) pp.57-64

\section{Contribution of individual authors to the creation of a scientific article (ghostwriting policy)}

Ahmad Dahiyat was responsible for the introduction and theoretical aspects of the study, and the discussion and conclusion and recommendations.

Esra Al-Nsour was responsible for extracting and preparing the financial measures of the study and was responsible of Statistics.

Follow:

www.wseas.org/multimedia/contributorrole-instruction.pdf

Creative Commons Attribution

License 4.0 (Attribution 4.0

International , CC BY 4.0)

This article is published under the terms of the Creative Commons Attribution License 4.0 https://creativecommons.org/licenses/by/4.0 /deed.en US 